\title{
Successional changes of epibiont fouling communities of the cultivated kelp Alaria esculenta: predictability and influences
}

\author{
A. M. Walls ${ }^{1, *}$, M. D. Edwards ${ }^{1}$, L. B. Firth ${ }^{2}$, M. P. Johnson ${ }^{1}$ \\ ${ }^{1}$ Irish Seaweed Research Group, Ryan Institute, National University of Ireland, Galway, Ireland \\ ${ }^{2}$ School of Geography, Earth \& Environmental Science, Plymouth University, Drake Circus, Plymouth PL4 8AA, UK
}

\begin{abstract}
There has been an increase in commercial-scale kelp cultivation in Europe, with fouling of cultivated kelp fronds presenting a major challenge to the growth and development of the industry. The presence of epibionts decreases productivity and impacts the commercial value of the crop. Several abiotic and biotic factors may influence the occurrence and degree of fouling of wild and cultivated fronds. Using a commercial kelp farm on the SW coast of Ireland, we studied the development of fouling communities on cultivated Alaria esculenta fronds over 2 typical growing seasons. The predictability of community development was assessed by comparing mean occurrence-day. Hypotheses that depth, kelp biomass, position within the farm and the hydrodynamic environment affect the fouling communities were tested using species richness and community composition. Artificial kelp mimics were used to test whether local frond density could affect the fouling communities. Species richness increased over time during both years, and species composition was consistent over years with early successional communities converging into later communities (no significant differences between June 2014 and June 2015 communities, ANOSIM $; R=-0.184, p>0.05$ ). The timing of species occurrences was predictable across years for all shared species. Variations in biomass, depth and position within the farm had no significant effect on species richness and composition. Results from artificial kelp mimics suggest possible hydrodynamic effects. The ability to understand succession and the timing of occurrences of fouling organisms and predict their arrival has significant benefits for the seaweed cultivation industry.
\end{abstract}

KEY WORDS: Alaria esculenta · Macroalgae · Aquaculture · Frond · Fouling • Epibiont · Predictability $\cdot$ Influences

\section{INTRODUCTION}

Traditionally, the cultivation of kelp has primarily been restricted to Asia (Murata \& Nakazoe 2001) with comparatively lower biomass cultivated in European waters. However, over the last few years interest in kelp cultivation in Europe has increased, supported by feasibility studies (e.g. Bruton et al. 2009) and experimental farms which are being set up to begin to industrialise the industry and advance the cultivation of kelps native to this region (including several research projects, e.g. At $\sim$ Sea 2015, www.atsea-

${ }^{*}$ Corresponding author: a.walls2@nuigalway.ie

$\S_{\text {Corrections were made after publication. For details see }}$ www.int-res.com/abstracts/aei/v9/c_p57-71

This version: February 27, 2017 project.eu; EnAlgae 2015, www.enalgae.eu; and MAB3 2015, www.mab3.dk). This interest includes Ireland with the establishment of Dingle Bay Seaweed in Ventry Harbour, County Kerry, in 2011 as one of the larger commercial kelp farms (18 ha) in Europe (M. D. Edwards pers. obs.).

A major challenge to the development and growth of the seaweed sector is the undesirable attachment of fouling organisms on kelp fronds. These organisms will be referred to collectively as epibionts, with the terms epifauna and epiphytes referring to animal and alga epibionts, respectively (Wahl 1997). The pres-

(C) The authors 2017. Open Access under Creative Commons by Attribution Licence. Use, distribution and reproduction are unrestricted. Authors and original publication must be credited.

Publisher: Inter-Research · www.int-res.com 
ence of epibionts decreases the productivity of farms (Fletcher 1995, Peteiro \& Freire 2012) and impacts the commercial value of the crop (Park \& Hwang 2012). The negative impacts of fouling on seaweeds have been well documented for both wild and cultivated fronds. These include a potential loss of biomass, as fouling organisms can affect the flexible nature of kelp, resulting in increasing breakage of fronds (Dixon et al. 1981, Krumhansl et al. 2011). Individuals can be torn from substrata due to increased drag from epibionts (Dayton 1985, D'Antonio 1985). Frond fouling can also lead to necrosis of kelp tissue (Fletcher 1995, Peteiro \& Freire 2013b) and the inhibition of reproduction by preventing spore release (D'Antonio 1985, Saier \& Chapman 2004). Photosynthesis can be decreased as fouling organisms can create a barrier to nutrient uptake (Hurd et al. 2000), can block the surface area of the frond (Hepburn et al. 2006) and restrict light availability (Cancino et al. 1987). In addition, heavily fouled fronds have a lower market value as they are considered to be unsuitable for human consumption due to a degradation of taste and quality (Park \& Hwang 2012, Peteiro \& Freire 2013b, Getachew et al. 2015). Lower-value fronds are instead used for animal feed (Bruton et al. 2009) and severely fouled fronds are discarded (Peteiro \& Freire 2013b).

Outside Europe, research has been conducted on the fouling organisms associated with cultivated seaweeds for many decades. For example, studies of Gracilaria sp. farming in Chile, which mainly focused on epiphytes (Buschmann \& Gómez 1993, Fletcher 1995, Leonardi et al. 2006) and kelp farming in Asia, with a focus on fouling hydroids and copepods (Park et al. 1990, 2008, Park \& Hwang 2012). However, due to the slower growth of the cultivation industry in Europe, research on associated epibionts has only begun more recently (Peteiro \& Freire 2013b, Førde et al. 2016, Walls et al. 2016). Similar species have been found to be responsible for fouling on both wild and cultivated kelp fronds, including bryozoans (Førde et al. 2016), hydroids, amphipods, harpacticoid copepods and gastropods (Norton et al. 1977, Seed \& Harris 1980, Park et al. 2008, Park \& Hwang 2012, Peteiro \& Freire 2013b). Among the few published studies that exist, often only an investigation of fouling communities at the end-point of the cultivation period has been conducted (Peteiro \& Freire 2013b). In other cases the development of a single group or a fouling species that may have a major negative effect on the fronds has been followed in isolation over the growing season (Park et al. 2008, Park \& Hwang 2012, Førde et al. 2016).
Both abiotic and biotic factors are known to influence the occurrence and degree of fouling on the fronds of both wild and cultivated kelps (Vairappan 2006, Peteiro \& Freire 2013b). Abiotic factors include seasonal variation of environmental parameters (temperature, light and salinity), location, hydrodynamics and depth. Cultivated kelps are generally deployed in winter and harvested in early summer to match the natural growing season of their wild kelp counterparts, and this coincides with temperature and light increases which also bolster the growth of epibiotic organisms. Vairappan (2006) found that outbreaks of epiphytes on farmed Gracilaria sp. were correlated with drastic changes in seawater temperature and salinity. Increasing water temperatures have also been associated with hydroid and copepod infestations on cultivated kelps in Korea (Park et al. 2008, Park \& Hwang 2012). Peteiro \& Freire (2013b) found that within a bay on the northwest coast of Spain, higher fouling occurred in a sheltered area of the bay than in a more exposed area. On a smaller spatial scale, location within the farm may also have an effect, as the outer areas of the farm may receive greater water flow and correspondingly exhibit less fouling than in the sheltered middle area of the farm (Peteiro \& Freire 2013b). The hydrodynamics around fronds may be influenced by frond density, with different water movement occurring around densely growing fronds compared with fronds growing at lower densities, which in turn will effect frond fouling (Peteiro \& Freire 2013b, Peteiro et al. 2016). The position of fronds in the water column has also been found to have an impact on fouling organisms. Førde et al. (2016) found that bryozoan population densities decreased with increasing depth of cultivated kelp in Norway.

Biotic factors found to have an influence on frond fouling include kelp age, frond morphology, secondary metabolite production and interactions between fouling organisms. Kelp fronds grow from the meristematic region at the base of the frond, so the tip or distal end of the frond is the oldest part of the frond and can have more fouling than younger parts of the frond (Jennings \& Steinberg 1997, Park et al. 2008, Park \& Hwang 2012, Zagal et al. 2013). This may simply be a reflection of accumulation and growth of epibionts over time (Jennings \& Steinberg 1997) or reduced physiological activity within the older tissue (Park \& Hwang 2012) allowing greater colonisation by organisms. Frond morphology, such as surface roughness and thickness, has also been found to affect fouling (Jennings \& Steinberg 1997, Peteiro \& Freire 2013b). Fletcher \& Day (1983) found no signif- 
icant difference in epifaunal abundance between smooth and crinkled Ecklonia radiata fronds; however, diversity was greater on the more complex habitat of the crinkled fronds than on the smooth fronds. Many large brown algae, including kelps, produce antifoulants, which may hinder growth and settlement of fouling organisms (Al-Ogily \& KnightJones 1977) and may be significant in determining epibiont abundance and species richness (Blight \& Thompson 2008, but see Jennings \& Steinberg 1997). Interactions between fouling organisms such as grazer abundance and predation can in turn affect the abundance and distribution of other fouling organisms. Marzinelli et al. (2011) modelled the presence of artificial habitats such as pilings on sea urchin abundance and found that a decrease in the abundance of sea urchins caused an increase in the cover of fouling bryozoans on kelp. In addition, competition between species can have an effect. For example, Førde et al. (2016) studied 2 bryozoan species on cultivated Saccharina latissima in Norway and found that competition between the 2 species occurred through overgrowing and habitat selection (Ryland 1962, Seed \& O'Connor 1981).

The kelp Alaria esculenta (Linnaeus) Greville is an economically valuable seaweed which is mainly cultivated for human consumption as it is rich in sugars, vitamins and protein (Guiry \& Blunden 1991). Also known as 'Atlantic Wakame', it is similar to the true 'Wakame' Undaria pinnatifida which is extensively cultivated in Japan, eastern China and South Korea (Yamanaka \& Akiyama 1993). A. esculenta has been cultivated in Ireland for the last 15 yr (Kraan \& Guiry 2001) and is an economically attractive species due to its high growth rate of up to $10 \mathrm{~cm} \mathrm{~d}^{-1}$ (Druehl et al. 1988), as well as being native to Irish coastal waters (Kraan \& Guiry 2001). Other uses of A. esculenta include animal fodder, biochemical extracts used in cosmetic products and the production of alginates, as it contains up to $42 \%$ alginic acid (Kraan \& Guiry 2001). A. esculenta is already one of the most cultivated species in Ireland (M. D. Edwards pers. obs.) and worldwide demand for cultivated kelp is expected to continue to expand (FAO 2016). There is a paucity of literature on the ecology of fauna associated with wild $A$. esculenta, possibly due to difficulties in sampling the wave-exposed rocky shores where this species is typically found (Kraan et al. 2000). Future expansion of $A$. esculenta cultivation requires an understanding of the associated epibionts, particularly to inform seaweed farmers on the best time to harvest their crop to reduce losses of biomass as a result of the presence of fouling organisms.
Given the importance of fouling to commercial kelp production and the gaps in knowledge of the communities associated with cultivated A. esculenta, the main aim of this study was to describe the development of fouling communities on the fronds of cultivated $A$. esculenta over a typical growing season. This was conducted by identifying all associated epibionts during different times of the cultivation period to track changes in community composition and development. We tested the predictability of epibiont communities from one growing season to the next by comparing their mean occurrence-day. If the fouling sequence is predictable, this would allow farmers to estimate the optimal time for harvesting before fouling decreases the value of the crop. Alternative hypotheses that depth, kelp biomass, position within the farm and the hydrodynamic environment have effects on fouling communities were tested using the species richness and community composition of fouling communities on cultivated fronds. Artificial kelp mimics were used to test whether local frond density could affect the fouling communities, with the null hypothesis being that local (frond scale) changes in current speeds associated with blade density are not sufficient to modify fouling assemblages.

\section{MATERIALS AND METHODS}

\section{Study site}

This study was conducted in the southwest coast of Ireland in Ventry Harbour, County Kerry (52 06' $49.45^{\prime \prime}$ N, $10^{\circ} 21^{\prime} 20.17^{\prime \prime}$ W; Fig. 1), at the largest operating commercial seaweed farm in Ireland (18 ha site). Ventry Harbour is a moderately sheltered and shallow embayment orientated towards the southeast, approximately $2.5 \times 1.5 \mathrm{~km}\left(3.75 \mathrm{~km}^{2}\right)$ with a wide mouth opening into Dingle Bay. Zostera marina (seagrass) is extensively distributed throughout the sandy seabed, leading to a rocky boulder reef towards the mouth of the bay. The licensed seaweed farm is orientated northwest to southeast, and located to the westerly side of Ventry Harbour (Fig. 1). The depth underneath the farm is approximately $6 \mathrm{~m}$ at the northwestern end before gently sloping to $20 \mathrm{~m}$ at the eastern edge of the farm at mean low water spring tide (MLWS). The tidal range in Ventry Harbour is between 0.6 and $4.0 \mathrm{~m}$. Irradiance values, obtained from nearby Valentia weather observatory $\left(51^{\circ} 56^{\prime} 23^{\prime \prime} \mathrm{N}, 10^{\circ} 14^{\prime} 40^{\prime \prime} \mathrm{W}\right)$, ranged from 5447 to $63823 \mathrm{~J} \mathrm{~cm}^{-2}$ for 2014. Sea surface temperature data was obtained from the M3 offshore weather buoy 


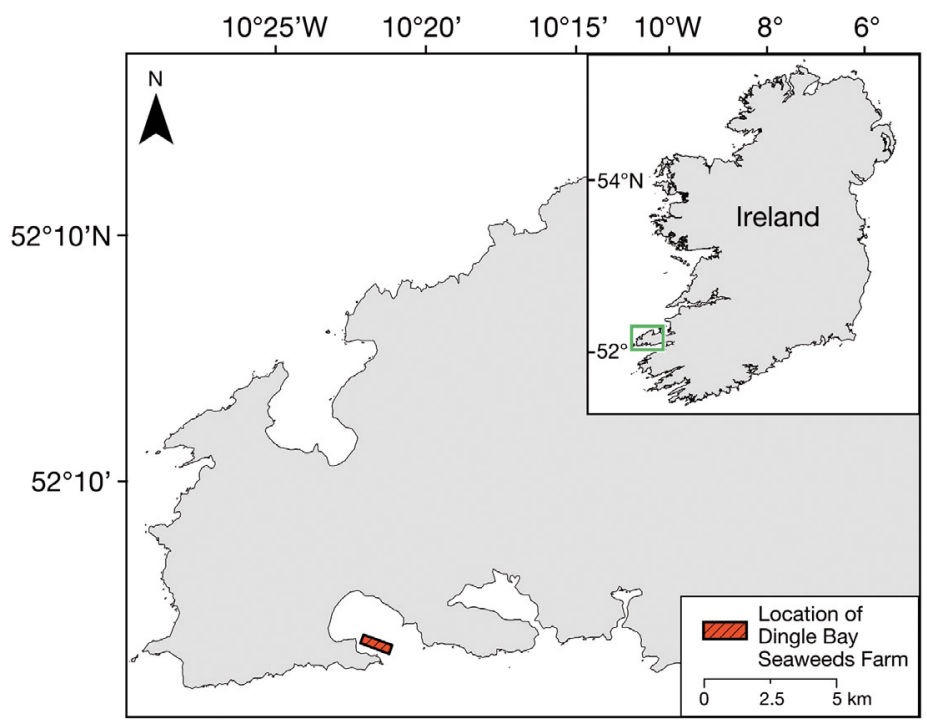

Fig. 1. Dingle Bay Seaweeds farm and sampling site at Ventry Harbour, County Kerry, Ireland

located approximately $56 \mathrm{~km}$ southwest of Mizen head $\left(51^{\circ} 13^{\prime} 0^{\prime \prime} \mathrm{N}, 10^{\circ} 33^{\prime} 0^{\prime \prime} \mathrm{W}\right)$, and ranged from 10.1 to $17.6^{\circ} \mathrm{C}$ for 2014 . Although offshore values are less extreme than inshore values, Ventry Harbour is a well flushed bay, so values are broadly representative. The longline structure is similar to the set-up in Walls et al. (2016, their Fig. 3); however, the farm in Ventry consists of 3 parallel units of $280 \mathrm{~m}$ linear longlines suspended approximately $1.5 \mathrm{~m}$ below the sea surface, and the dropper ropes used in this study were $1 \mathrm{~m}$ in length. The longlines were kept in position by buoys attached to the header rope and by $1500 \mathrm{~kg}$ anchor blocks at either end of the lines. The farm cultivates the kelps Alaria esculenta and Saccharina latissima for human consumption, animal feed and use in cosmetic products.

\section{Experimental set-up}

Experimental treatments were based on $1 \mathrm{~m}$ polypropylene dropper ropes (10 $\mathrm{mm}$ diameter) with 2 initial set-ups. Treatment 1 consisted of droppers sprayed directly with juvenile $A$. esculenta sporophytes that had been developed from gametophyte cultures held in the seaweed hatchery at the NUIG Carna Research Station (County Galway), following standard industry protocols (Fig. 2a). The seeded dropper ropes were left to develop under controlled growth conditions (Edwards \& Watson 2011) for 5 to $12 \mathrm{wk}$. There was a longer duration until deployment in Year 1 due to considerable winter storms that occurred in early 2014. Sporophytes were ca. $10 \mathrm{~mm}$ at time of deployment. Treatment 2 dropper ropes supported an artificial seaweed habitat (Fig. 2b). This included individual $A$. esculenta frond-shaped structures measuring ca. $1.5 \mathrm{~m}$ in length and $10 \mathrm{~cm}$ width, using $1200-$ gauge Visqueen damp proof membrane plastic. The size of these plastic fronds replicated the size of individuals measured in June at the Ventry Harbour site, averaged over a number of cultivation seasons. The plastic fronds were inserted into the $10 \mathrm{~mm}$ polypropylene rope and secured. Untwisted and frayed polypropylene rope was then wrapped around the dropper rope to create artificial holdfasts, mimicking the morphology of cultivated A. esculenta holdfasts by creating many interstitial spaces between the rope strands. Artificial substrate droppers were deployed at 2 different densities: high density droppers consisted of 60 sporophytes $\mathrm{m}^{-1}$ and low density of droppers consisted of 20 sporophytes $\mathrm{m}^{-1}$. Assemblages on artificial kelp mimics were compared to seeded kelp fronds to determine if they rep-

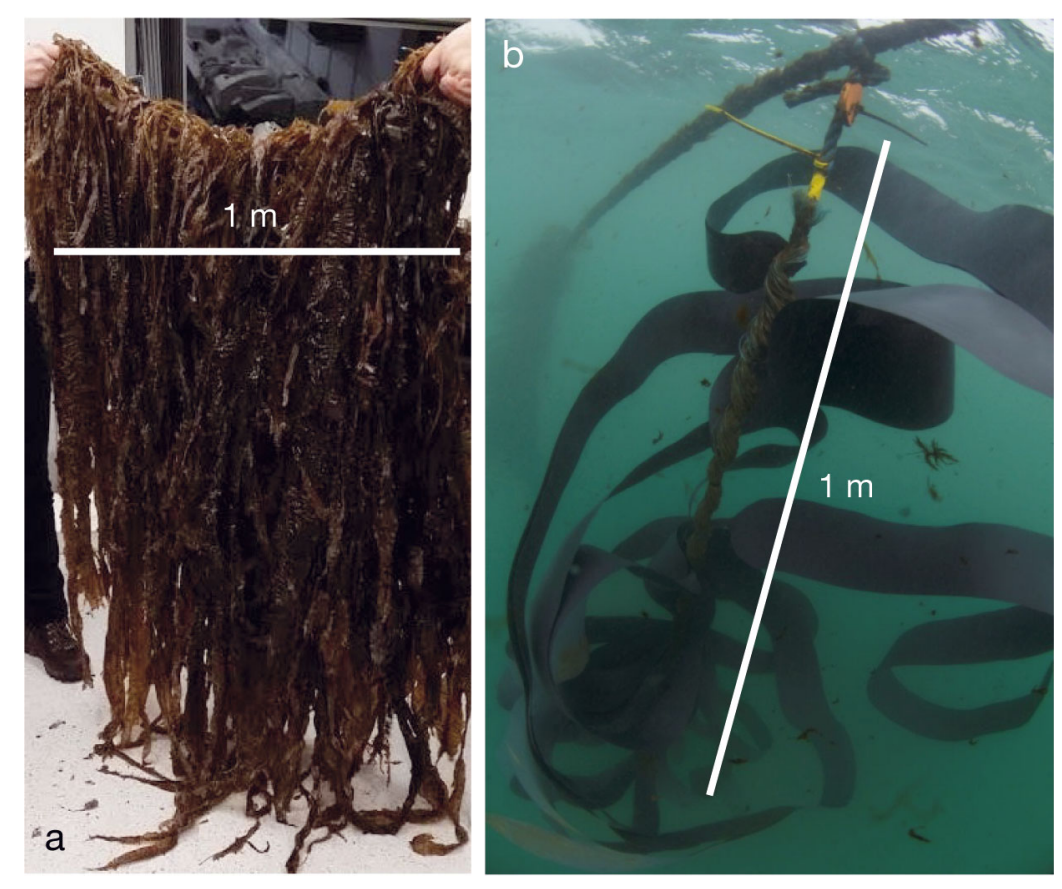

Fig. 2. (a) Seeded Alaria esculenta dropper in May 2015 (6 mo deployment), and (b) artificial low density A. esculenta dropper in May 2014 (3 mo deployment). Each dropper is $1 \mathrm{~m}$ in length 
resented a good analogue for living kelp. Treatment 2 (artificial seaweed) droppers were submerged in tanks of seawater under the same laboratory conditions as the seeded droppers for the same length of time prior to deployment. At deployment, all dropper replicates had a $1 \mathrm{~kg}$ concrete weight attached to the end of the rope and were deployed vertically on the longline header rope, spaced $1.5 \mathrm{~m}$ apart to mitigate against rubbing and tangling (Walls et al. 2016). Dropper ropes were suspended at a depth of 1.5 to $2.5 \mathrm{~m}$ below the surface, which is a depth range experienced at commercial seaweed farms. Each dropper was randomly assigned to a location on the longline header rope prior to deployment. Seeded $(n=35)$ and artificial (high, $\mathrm{n}=10$ and low, $\mathrm{n}=10$ density) droppers were deployed on 18 February 2014 for the 2013/2014 growing season (Year 1); deployment was delayed due to winter storms in early 2014. The experiment was repeated for the 2014/2015 growing season (Year 2), when the seeded $(n=35)$ treatment was deployed on 15 December 2014.

\section{Sampling protocol for seeded and artificial A. esculenta droppers}

All samples were collected by SCUBA divers. In April, May and June 2014 and 2015, 5 droppers were randomly chosen and collected from the seeded treatment using open-ended mesh bags $(150 \times 55 \mathrm{~cm}$, $0.5 \mathrm{~mm}$ mesh size). If the dropper was not uniformly covered in developing sporophytes (i.e. showed evidence of rubbing or entanglement), another dropper replicate was selected. The mesh bag was carefully slipped over the dropper and tightly secured at top and bottom (just above the weight) using cable ties, enclosing the entire $1 \mathrm{~m}$ dropper and kelp biomass. In June 2014, 5 artificial high density droppers and 5 artificial low density droppers were sampled using the mesh bags as described above. Unfortunately, it was not possible to isolate and sample only the stipe and frond material, as this would involve cutting fronds from suspended holdfasts in situ, potentially dislodging and losing mobile or loosely attached fauna (Walls et al. 2016). Frond fauna are dominated by sessile organisms (e.g. bryozoans and hydroids) and less mobile species (e.g. molluscs) and thus are less likely to move and contaminate neighbouring samples (Park et al. 2008, Peteiro \& Freire 2013b, Førde et al. 2016). All samples were processed within $6 \mathrm{~h}$. The mesh bags were untied before randomly pre-selected $10 \mathrm{~cm}$ sections $(\mathrm{n}=3)$ of each dropper were excised from the $1 \mathrm{~m}$ dropper (Fig. 2a). In the rare event that any randomly selected section of seeded dropper was not entirely covered in sporophytes, an alternative section was chosen. The fronds and stipes of seeded and artificial samples were cut just above the holdfast and stored in sealed plastic bags containing $100 \%$ ethanol. Holdfasts still attached to the section of dropper were stored in additional sealed plastic bags containing 100\% ethanol.

\section{Sample processing}

The stipe and frond samples from each $10 \mathrm{~cm}$ replicate section of dropper were removed from the plastic bags and rehydrated in freshwater for at least $1 \mathrm{~h}$ to allow the material to soften so they could be handled without breakage. From a preliminary study we calculated species accumulation curves, and found that processing $60 \mathrm{~g}$ of frond material per $10 \mathrm{~cm} \mathrm{sec-}$ tion was sufficient to sample the majority of fauna present for each sampling month. Processing $60 \mathrm{~g}$ of frond material from each section in each month allowed uniform comparison across seeded sampling months. For the artificial droppers we found that processing 1 frond per sample was sufficient to encapsulate the majority of species present for both the high and low density droppers. Both the front and back of seeded and artificial fronds were analysed during processing.

After the preliminary study had been concluded, further sample processing was carried out. Presence/ absence quantification of species richness was conducted on samples rehydrated in freshwater. Fronds were randomly selected from a tray and observed under the microscope for 2 min intervals; species present were identified and the weight of frond sample was recorded. This was repeated until the pre-defined weight of $60 \mathrm{~g}$ was achieved. The weight of the excess frond material not processed was recorded to obtain the total biomass per sample. All epifauna were identified to species level where possible using Hayward (1988) and Hayward \& Ryland (2002), with taxonomy cross-checked using web resources (WoRMS Editorial Board 2016). Epiphytes were identified using Bunker et al. (2012) and taxonomic specialist confirmation from the Irish Seaweed Research Group.

\section{Statistical analysis}

The data were analysed as a 4 -factor nested design with section, dropper, month and year nested within each other. This design was used to test the differ- 
ences between species richness and sampling years and months for seeded samples using fully nested analysis of variance (ANOVA). Fully nested ANOVA was also employed to test for differences between total sample weight and sampling years and months for seeded samples. All data were checked for normality by visual inspection of the residuals, and assumptions for ANOVA were met. The differences between faunal assemblage composition of frond samples from different months and years for the seeded treatments and high and low density treatments for the artificial samples were compared using multivariate tests. A Simpson's dissimilarity matrix was generated from the presence/absence data for the 6 seeded sampling dates (April, May and June, 2014 and 2015) and the 2 artificial treatments separately using the PopTools (Hood 2014) add-on in Excel. Simpson's dissimilarity has the advantage that it only measures the turnover of species and is not affected by changes in species richness between samples (Baselga 2010). This makes dissimilarities measured by Simpson's index easier to interpret than indices that mix turnover and species richness components of dissimilarity (e.g. Sørenson's index). Multidimensional scaling (MDS; Shepard 1962, Kruskal 1964a,b) ordination was carried out using PRIMER V6® (Clarke \& Gorley 2006), giving the position of each frond sample in 2-dimensional (2D) space based on its species composition.

Where significant differences between sampling dates and treatments were detected, a variation on SIMPER analysis was conducted to highlight the species that contributed most to the observed differences. The SIMPER programme in PRIMER could not be used as Simpson's dissimilarity is not compatible with the algorithm used in the programme. Instead, we conducted a SIMPER-like analysis, hereafter referred to as a test of species influence, by comparing the observed dissimilarity within and between samples when all species were included to the dissimilarities generated by excluding each species individually. The average between-group and within-group dissimilarities were compared to determine whether omitting a species made the groups appear more or less similar. In summary, if a species makes groups more similar when excluded from the matrix, it suggests that the species makes a contribution to the observed differences between groups. Ratios of between- to within-group dissimilarities were normalized to facilitate comparisons. Any species $>1$ SD of the mean normalized score was identified as having an above average contribution to the overall dissimilarity between the groups.
To test the predictability of the fouling of shared species from Year 1 (2014) to Year 2 (2015), we used day of year to calculate the central tendency of species occurrence. This central tendency is the average day when a species was observed, weighted by occurrence when observed. Day of year is the number assigned to a whole solar day that starts at 1 on 1 January and finishes at 365 on 31 December (nonleap year). The central tendency method as described by Colebrook (1979) is sensitive to changes in the timing of seasonal cycles (Edwards \& Richardson 2004, Moore et al. 2011). A regression of year 2014 and 2015 mean species occurrence against each other for all commonly occurring species is expected to be significant with a slope close to 1 if the temporal pattern of fouling is similar from year to year.

Tests of association were used to examine the relationships between fouling and different biotic and abiotic factors. The relationship between total sample biomass and the square root of species richness was assessed using Pearson's product moment correlation. Inspection of residual plots revealed that square root transformation was appropriate. The effect of total seeded biomass on community structure within individual months was investigated using multivariate tests. The RELATE procedure in the PRIMER community analysis programme (Clarke \& Warwick 1994) was used to test if samples with larger total biomass had different community composition within individual months. We compared a Simpson's dissimilarity matrix of species presence/absence data with a matrix of similarities based on Euclidean distances for total sample weight. Pearson's product moment correlation was used to identify any correlations between sample depth along the dropper and square root-transformed species richness. We again conducted a RELATE test to assess the relationship between sample depth and species composition. The location of dropper position in sequence along the longline was assessed as another possible factor affecting species richness (square root) using Pearson's product moment correlation. Additionally, the effect of dropper location on species composition was assessed using exploratory MDS ordinations in PRIMER to visually assess the potential for gradients across the sample site. This was considered more robust than analysing a directional gradient (e.g. east-west) as there was no hypothesis for the type of spatial pattern expected. Potential patterns included a clustering of east and west samples to either edge of the plot with middle samples in between, or east and west samples forming a circle around the middle samples. 


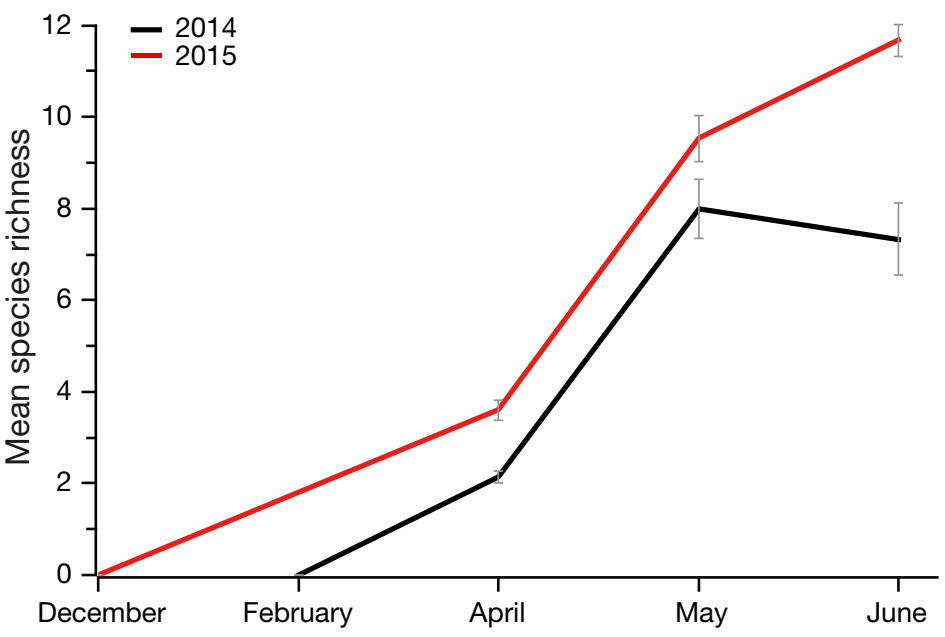

Fig. 3. Species richness (mean $\pm \mathrm{SE}$ ) on seeded Alaria esculenta fronds sampled in April, May and June 2014 and 2015. Species richness represents the number of taxa identified on $60 \mathrm{~g}$ subsamples from each $10 \mathrm{~cm}$ section $(n=3)$ from each dropper $(n=5)$

$9.94 \%$ was explained by the section replicates. The 2015 samples may have had more species in a pairwise comparison, but the ANOVA design tested whether the effect of years was greater than the seasonal effects; it was not.

Significant differences in total sample biomass were recorded between sampling months (April, May and June) from the fully nested ANOVA (Table 2); again, year was not a significant factor. A variance component analysis showed that $16.09 \%$ of the variance was between months with $15.91 \%$ variance between droppers and $<1 \%$ explained by year; the remaining $67.83 \%$ was explained by the section replicates.

Some separation and clustering of fouling assemblages of $A$. esculenta seeded fronds can be seen between months in the MDS plot (Fig. 4). A stress value of 0.15 indicates a reliable $2 \mathrm{D}$ representation of the data (Clarke \&

\section{RESULTS}

A total of 44 fouling species were recorded on seeded and artificial Alaria esculenta fronds; 22 species were recorded on 2014 seeded samples, 32 species on 2015 seeded samples and 35 species on artificial frond samples from June 2014. Species richness for seeded samples in 2014 ranged from 4 species in April to 17 in June, and from 9 in April to 22 in June for 2015 samples. In total, 30 species were recorded from the low density artificial fronds and 27 species were recorded from the high density artificial fronds. Crustaceans were the most species-rich group in all samples. A full species list with occurrence per sample is supplied in Table S1 in the Supplement at www.int-res.com/articles/suppl/009p057_supp.pdf.

\section{Community composition and development of fouling organisms on seeded $A$. esculenta fronds over the growing season}

Species richness increased after the replicate treatments were deployed at the site in Ventry (Fig. 3). Significant differences in species richness were recorded between sampling months (April, May and June) and droppers from the fully nested ANOVA (Fig. 3, Table 1); however, the factor year was not significant. A variance component analysis showed that $86 \%$ of the variance was between months with $4.04 \%$ variance between droppers; year did not account for any of the variance, and the remaining
Warwick 1994). The pattern shows clear clustering of communities into distinct early April communities to later May and June communities, which show little separation. There is no clear separation of community assemblages between 2014 and 2015, indicating similar communities were present over both years.

Table 1. Fully nested ANOVA of species richness with dropper (1 to 5) nested in month (April, May and June) nested in year (2014 and 2015). F-ratio of within-group to betweengroup variation; ${ }^{*} \mathrm{p}<0.05$

\begin{tabular}{|lrrrrr|}
\hline Source & df & SS & MS & \multicolumn{1}{c|}{$F$} & \multicolumn{1}{c|}{$\mathrm{p}$} \\
\hline Year & 1 & 132 & 132 & 0.647 & 0.466 \\
Month & 4 & 815 & 203 & 59.299 & $<0.001^{*}$ \\
Dropper & 24 & 82 & 3 & 2.227 & $0.006^{*}$ \\
Error & 60 & 92 & 1 & & \\
Total & 89 & 1122 & & & \\
\hline
\end{tabular}

Table 2. Fully nested ANOVA for total sample biomass at different times: sampling year (2014 and 2015) and sampling months (April, May and June). F-ratio of within-group to between-group variation; ${ }^{*} \mathrm{p}<0.05$

\begin{tabular}{|lrcrrc|}
\hline Source & df & SS & MS & \multicolumn{1}{c|}{$F$} & $\mathrm{p}$ \\
\hline Year & 1 & 134776 & 134776 & 1.022 & 0.369 \\
Month & 4 & 527663 & 527663 & 3.088 & $0.035^{*}$ \\
Dropper & 24 & $1.02510 \times 10^{6}$ & 42712 & 1.704 & $0.049^{*}$ \\
Error & 60 & $1.50421 \times 10^{6}$ & 25070 & & \\
Total & 89 & $3.19175 \times 10^{6}$ & & & \\
\hline
\end{tabular}




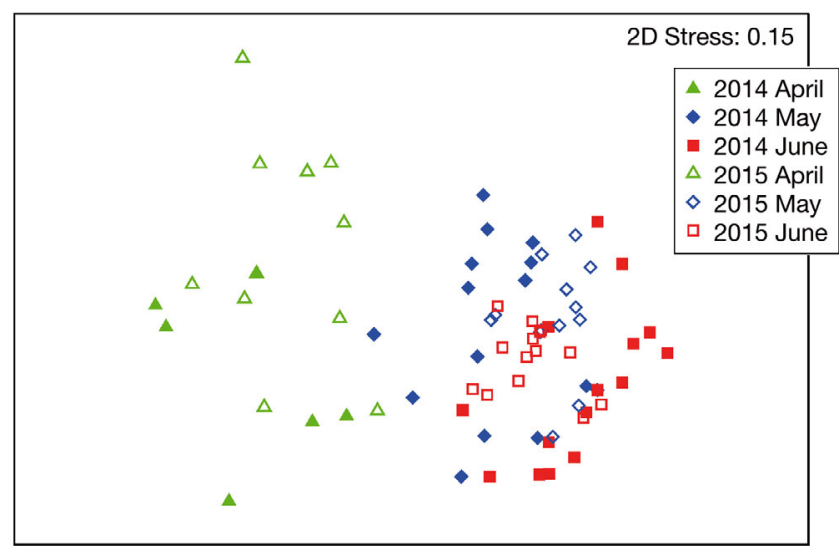

Fig. 4. Two-dimensional multidimensional scaling plot of 89 Alaria esculenta frond sections: 44 from the 2014 sections (one April section had no species present so was removed) and 45 from the 2015 sample, based on presence/absence Simpson's dissimilarity matrix of species collected from each frond section $($ stress $=0.15)$

Differences in assemblage composition among different sampling months and years were found to be significant (ANOSIM; $\mathrm{R}=0.628, \mathrm{p}<0.001$ ). All pairwise combinations of dates indicated significant differences except June 2014 and May $2015(R=0.142$, $\mathrm{p}>0.05)$ and June 2014 and June $2015(\mathrm{R}=-0.184$, $\mathrm{p}>0.05)$.

A test of species influence analysis was conducted to determine which taxa were the most influential in causing differences in assemblage structure of A. esculenta fronds between sampling months and years (Table 3). Filamentous brown alga sp. was a major contributor to the observed differences between
April and May samples in 2014 and 2015. Occurrence of filamentous brown algae sp. was at its maximum in April and was low in May (between 0 and 2 samples). The bryozoan Membranipora membranacea was a driver of the dissimilarity between May and June 2014 samples, being present in 6 samples in May and 15 in June. The bivalve mollusc Anomia ephippium and the polychaete Eulalia viridis were important discriminatory samples between May and June 2015. Comparing months from different years, Obelia geniculata accounted for differences between April 2014 and 2015 frond samples. The polychaetes Myrianida sp. and Spirobranchus triqueter and the gastropod Lacuna vincta were important contributors to the observed differences between May 2014 and 2015 samples. From the dissimilarity scores in Table 3, May and June 2014 and 2015 samples were less dissimilar than April and May 2014 and 2015 samples, and May 2014 and 2015 samples were less dissimilar than April 2014 and 2015 samples - showing not only do the samples converge over months but they also converge over different years, resulting in the June 2014 and 2015 community assemblages not being significantly different (ANOSIM).

\section{Predictability of fouling organisms on seeded \\ A. esculenta fronds}

The timing of species occurrences was consistent across years for all shared species in 2014 and 2015. The regression slope relating mean day of year species occurrence in 2014 to mean day of year species

Table 3. Test of species influence to determine the epifaunal species contributing to observed differences in the structure of Alaria esculenta frond assemblages between months and years. Dissimilarity scores are the ratio of average between-group dissimilarities to within-group dissimilarities for each pairwise comparison. Normalized score is the reduction in dissimilarity score when excluding the species of interest, normalized to mean $=0, \mathrm{SD}=1$ using the mean and standard deviation of all individual species' scores. A higher loss in dissimilarity indicates that a species is important in distinguishing the dates compared

\begin{tabular}{|c|c|c|c|c|}
\hline Months & $\begin{array}{l}\text { Dissimilarity } \\
\text { score all species } \\
\text { included }\end{array}$ & $\begin{array}{l}\text { Species } \\
\text { responsible for } \\
\text { dissimilarity }\end{array}$ & $\begin{array}{l}\text { Normalized } \\
\text { score }\end{array}$ & $\begin{array}{c}\text { Species } \\
\text { occurrence } \\
\left(\max .15 \mathrm{mo}^{-1}\right)\end{array}$ \\
\hline April and May 2014 & 3.82 & Filamentous brown algae sp. & 2.64 & April: $14^{\mathrm{a}}$, May: 2 \\
\hline May and June 2014 & 1.60 & Membranipora membranacea & 3.90 & May: 6, June: 15 \\
\hline April and May 2015 & 3.01 & Filamentous brown algae sp. & 3.11 & April: 15, May: 0 \\
\hline May and June 2015 & 1.40 & $\begin{array}{c}\text { Eulalia viridis } \\
\text { Anomia ephippium }\end{array}$ & $\begin{array}{l}2.21 \\
2.98\end{array}$ & $\begin{array}{l}\text { May: 3, June: } 0 \\
\text { May: 0, June: } 13\end{array}$ \\
\hline April 2014 and April 2015 & 2.02 & Obelia geniculata & 2.28 & April (2014) $)^{\mathrm{a}}: 11$, April (2015): 2 \\
\hline May 2014 and May 2015 & 1.65 & $\begin{array}{l}\text { Myrianida sp. } \\
\text { Spirobranchus triqueter } \\
\text { Lacuna vincta }\end{array}$ & $\begin{array}{l}2.05 \\
2.11 \\
2.11\end{array}$ & $\begin{array}{l}\text { May (2014): 8, May (2015): } 3 \\
\text { May (2014): 0, May (2015): } 12 \\
\text { May (2014): 9, May (2015): } 3\end{array}$ \\
\hline
\end{tabular}

${ }^{a}$ In April 2014, the maximum occurrence was 14, as 1 sample had no species and was removed from all analyses 
occurrence in 2015 (Fig. 5) was significant, with $\mathrm{R}^{2}=$ 0.7703 , slope $=1.14( \pm 0.151 \mathrm{SE})$ and intercept $=$ $-20.24( \pm 22.958 \mathrm{SE})$. This describes a predictable occurrence pattern of common species between 2014 and 2015.

\section{Factors affecting community structure and species richness of seeded $A$. esculenta fronds}

Differences in fouling species richness and community composition did not seem to reflect replicate-specific variation in biomass, depth and dropper position. The relationship between total sample weight and the square root of species richness was not significant for all within-month correlations $(\mathrm{p}>$ 0.05), except the April 2014 sample which had a significant negative correlation $(\mathrm{r}=-0.613, \mathrm{p}=$ 0.015). The mean $( \pm \mathrm{SE})$ Pearson's correlation for 6 correlations conducted was $0.051 \pm 0.1391$. There was no relationship between Simpson's dissimilarity matrix for species composition and Euclidean distance matrix for total sample weight for replicates within individual sampling months. (RELATE test; number of tests $=6$, maximum $r=0.158$, minimum $p$ > 0.1). Depth of dropper sections did not have a significant effect on species richness when tested using Pearson's product moment correlation on the square root of species number for all sampling months (April, May, and June 2014/2015) ( $p$ > 0.1), with mean Pearson's correlation $0.091 \pm 0.0845$. There was no relationship between Simpson's dis- similarity matrix for species composition and Euclidean distance matrix for sample depth for replicates within individual sampling months (RELATE test; number of tests $=6$, maximum $r=0.157$, minimum $\mathrm{p}>0.1$. Dropper position on the longline and square root of species richness was not significant for all months ( $p$ > 0.05), except for the May 2015 samples which had significant negative correlation $(\mathrm{r}=-0.563, \mathrm{p}=0.029$; mean \pm SE Pearson's correlation: $-0.2083 \pm 0.1163$ ). The effect of dropper position on the longline was also assessed as a possible factor causing species compositional differences by visually examining 2D MDS plots (see Fig. S1 in the Supplement). However, no indication of a relationship was found, e.g. no clustering of either east or west samples.

\section{Comparison of seeded and artificial A. esculenta frond communities}

Some separation in assemblage composition between seeded and artificial high and artificial low density treatments sampled in June 2014 can be seen from the MDS plot (Fig. 6). A stress value of 0.25 indicated that the data are only partially represented by a 2D plot (Clarke \& Warwick 1994), and were better represented by a 3D plot (stress $=0.18$ ). Although Fig. 6 helps to illustrate this separation, it does not fully encapsulate the structure of the data. Subsequent nested ANOSIM results indicated a significant difference in assemblage composition $(\mathrm{R}=$

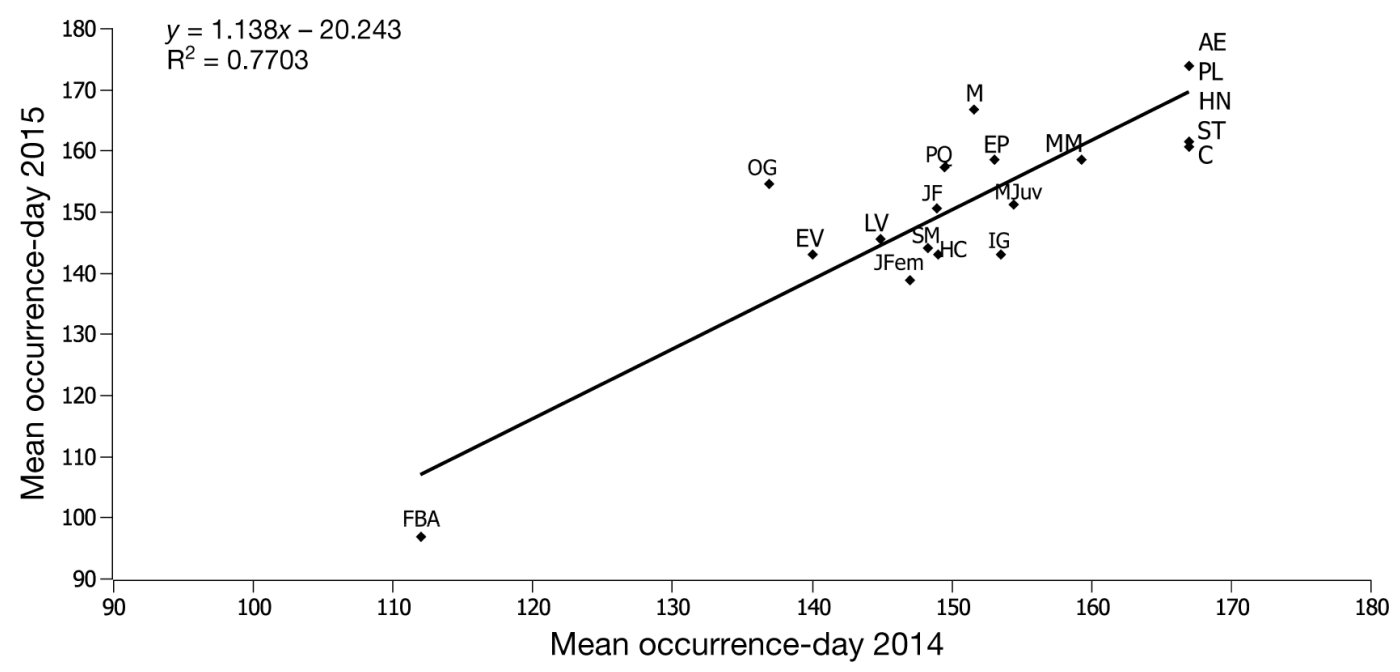

Fig. 5. Relationship between mean day of year occurrences for all shared species in 2014 and 2015 on the fronds of seeded Alaria esculenta. FBA: filamentous brown algae sp.; OG: Obelia geniculata; EV: Eulalia viridis; LV: Lacuna vincta; JFem: Jassa sp. female; SM: Stenothoe monoculoides; HC: harpacticoid copepods; JF: Jassa falcata; PQ: Polycera quadrilineata; IG: Idotea granulosa; MJuv: Mytilus sp. juvenile; EP: Electra pilosa; MM: Membranipora membranacea; M: Myrianida sp.; ST:

Spiro-branchus triqueter; C: Ceramium sp.; AE: Anomia ephippium; PL: Pisidia longicornis; HN: Hardametopa nasuta 


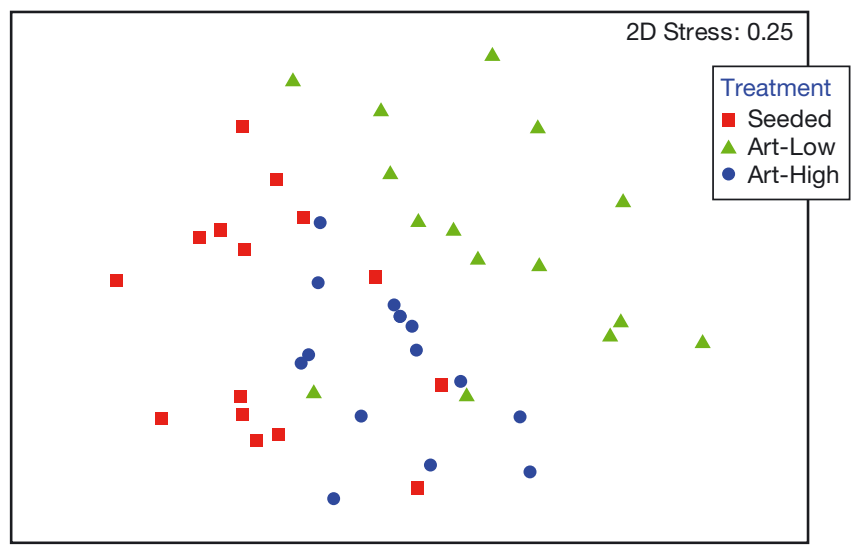

Fig. 6. Two-dimensional multidimensional scaling plot of 45 Alaria esculenta frond sections, 15 from seeded samples (filled red squares), 15 from artificial low samples (filled green triangles) and 15 from artificial high samples (filled blue circles), based on Simpson's dissimilarity matrix of species occurrence from each frond section sampled (stress $=0.25$ )

$0.176, \mathrm{p}<0.05)$. No significant differences were observed between seeded and artificial low density treatments $(R=0.268, p>0.05)$ or between seeded and artificial high density treatments $(\mathrm{R}=-0.136, \mathrm{p}>$ 0.05); however, significant difference were observed between artificial low and high treatments $(R=0.46$, $\mathrm{p}<0.01$ ) from the resulting pairwise tests.

As only the artificial treatments showed significant differences in community composition, a test of species influence was conducted to determine which taxa were the major contributors to this observed dissimilarity (Table 4). The red alga Ceramium sp., the nudibranch Polycera quadrilineata and the crustacean Necora puber were major contributors to the observed differences between treatments. Ceramium sp. and N. puber had higher occurrence on the low density fronds, whereas $P$. quadrilineata was more associated with the high density fronds.

Table 4. Test of species influence to determine the epifaunal species contributing to observed differences in the structure of Alaria esculenta frond assemblages between artificial treatments. Dissimilarity and normalized scores are as described for Table 3. A higher loss in dissimilarity indicates that a species is important in distinguishing the treatments compared

\begin{tabular}{|c|c|c|c|c|}
\hline $\begin{array}{r}\mathrm{Di} \\
\text { scor }\end{array}$ & $\begin{array}{l}\text { Dissimilarity } \\
\text { core all species } \\
\text { included }\end{array}$ & $\begin{array}{l}\text { Species } \\
\text { responsible for } \\
\text { dissimilarity }\end{array}$ & $\begin{array}{l}\text { Normalized } \\
\text { score and distance } \\
\text { from mean }\end{array}$ & $\begin{array}{c}\text { Species } \\
\text { occurrence } \\
\left(\text { max. } 15 \mathrm{mo}^{-1}\right)\end{array}$ \\
\hline \multirow{3}{*}{$\begin{array}{l}\text { Artificial low } \\
(\mathrm{AL}) \text { and artificial } \\
\text { high }(\mathrm{AH})\end{array}$} & 1.55 & Ceramium sp. & 3.23 & AL: $11 ; A H: 1$ \\
\hline & 1.55 & olycera quadrilineata & 3.92 & $\mathrm{AL}: 3 ; \mathrm{AH}: 15$ \\
\hline & 1.55 & Necora puber & 1.15 & AL: 7; AH: 0 \\
\hline
\end{tabular}

\section{DISCUSSION}

\section{Community composition and development of fouling organisms on seeded Alaria esculenta fronds over the growing season}

Fouling assemblages sampled from the fronds of cultivated Alaria esculenta followed a seasonal pattern, with a build-up of species over sampling months from zero species at time of deployment to over 20 species at the end of the study. The identified species have all been previously recorded as kelp fouling organisms from wild or cultivated kelp (Seed \& Harris 1980, Christie et al. 2003, Park et al. 2008, Park \& Hwang 2012, Peteiro \& Freire 2013b, Førde et al. 2016). Species richness of seeded kelp fronds in Ventry Harbour is within the range found from other studies of the fauna on wild kelp fronds (Sloane et al. 1957, Norton et al. 1977, Seed \& Harris 1980, Christie et al. 2003, Włodarska-Kowalczuk et al. 2009). The accumulation of fouling species richness on $\mathrm{A}$. esculenta fronds probably reflects seasonal factors influencing reproduction, dispersal and settlement. Fouling epibionts such as bryozoans, hydroids, molluscs and crustaceans begin to settle in spring and early summer (Hayward \& Ryland 2002, Park et al. 2008, Park \& Hwang 2012, Førde et al. 2016). We found a significant increase in species richness with each sampling month. Species richness in standardised samples was not linked with total sample biomass.

The multivariate analysis of assemblage development on A. esculenta fronds showed that species are not simply accumulated over time; there are compositional differences between early and later samples. Change in community composition was through addition of new species and replacement of early colonisers. April and May communities between 2014 and 2015 were significantly different, possibly due to differences in deployment time. From the test of species influence, these communities were distinguished by filamentous brown algae sp., which was dominant in April and dramatically decreased in May of both years, i.e. the species were replaced. May and June 2014 communities were differentiated by the bryozoan Membranipora membranacea, which settles later in the summer (Ryland \& Hayward 1977). The presence of the bryozoan Electra pilosa was higher early in the sampling season (May) of both years, but decreased as bryozoan coverage increased; M. mem- 
branacea was dominant in later sampling months (June). This development may be due to species' preference in substrate selection (Ryland 1962) and differing growth rates (Seed \& Harris 1980, Yorke \& Metaxas 2011). Our findings are consistent with the Førde et al. (2016) study of bryozoans on the fronds of cultivated Saccharina latissima in Norway and are examples of species replacement.

The convergence of the epibiont communities over different years is shown in the MDS plot (Fig. 4) and reflected in pairwise tests that showed no significant differences between June 2014 and May 2015 samples and June 2014 and 2015 samples, even with a 2 mo difference in deployment time. April 2014 and 2015 samples and May 2014 and 2015 samples were shown to be significantly different due to species occurrence, which may reflect variations in larval settlement times between years.

\section{Predictability of communities from one year to the next}

The convergence of fouling assemblages between different years suggests that species colonise fronds at similar times. The mean occurrence-day of fouling organisms on the fronds of seeded A. esculenta cultured in Ventry Harbour was predictable from one year to the next (Fig. 5), despite variations in deployment date and sampling date between years, and factors such as water temperature, turbidity, irradiance and salinity presumably also varying from one year to the next. It would be reasonable to expect that the degree of predictability would decline with increasing intervals between years or when comparing communities in different locations. Differences in shoreline topography such as headlands and embayments can modify local hydrodynamic processes, creating eddies and fronts that affect the dispersion of zooplankton (Alldredge \& Hamner 1980, McCulloch \& Shanks 2003). Local larval pools can regulate the diversity of species potentially able to settle at a site by setting an upper limit of species available (Herben 2005). Thus, the retention or export of larvae within or out of bays may influence the predictability and consistency of the fouling sequence within and between bays. Only highly mobile organisms or those with pelagic larval dispersal will be able to colonise and establish on suspended kelps (Walls et al. 2016). Using flushing times as a variable to describe the likelihood that larvae are retained in bays, Jessopp et al. (2007) investigated the effect of coastline configuration on larval assemblages. The authors found clear evidence that the physical characteristics of bays influence the local larval pool. Species richness was found to be higher in bays with longer flushing times, and conversely, species richness was lower in bays with shorter flushing times. Ventry Harbour is a shallow, medium sized embayment (ca. $3.75 \mathrm{~km}^{2}$ ) with a wide opening into Dingle Bay, and is likely to have a short flushing and thus lower species richness than more enclosed bays.

\section{Factors affecting fouling of seeded A. esculenta fronds}

None of the factors tested had a large influence on seeded fouling communities. Total sample biomass did not have an effect on species composition or species richness (exception: April 2014, possible Type I error), meaning that the effect of biomass was not a strong influence compared to other factors such as larval settlement and environmental conditions.

Depth of sections also had no relationship with species composition or species richness. One explanation could be that droppers were $1 \mathrm{~m}$ long and only suspended 1.5 to $2.5 \mathrm{~m}$ below the water surface, and this variation in depth was not large enough to cause an effect. Førde et al. (2016) found significantly less bryozoan cover with increasing depths up to $15 \mathrm{~m}$ on the fronds of cultivated S. latissima. However, droppers of $15 \mathrm{~m}$ length are not practical in commercial seaweed farms in Ireland where licensed sites are often located in depths less than $15 \mathrm{~m}$. Kelp growth is also affected by depth; however, optimum cultivation depth varies among latitudes (Buschmann et al. 2008, Handå et al. 2013, Peteiro et al. 2016). Thus, in addition to practical limitations, there is a probable trade-off between fouling and farm productivity linked to cultivation depth.

The position of droppers within the farm did not have an effect on community structure or species richness (exception: May 2015, possible Type I error). Droppers were positioned along a $280 \mathrm{~m}$ header rope; this distance may not have had great variations in environmental parameters such as exposure and turbidity. Larger-scale site differences may have an effect; e.g. Peteiro \& Freire (2013b) found that in a bay in NW Spain the abundance of epibionts was lower in an exposed site than in a sheltered site.

\section{Comparison of seeded and artificial A. esculenta frond communities}

Multivariate tests showed no significant differences between the seeded treatment and the artificial 
high and low density treatments. Interestingly, even though frond tissue type and size were different, the community assemblages were not. However, when the seeded treatment factor was removed, there was a significant difference between artificial density treatments, which suggests a density effect. We calculated a surface area to weight relationship for $A$. esculenta to assess how representative the artificial density treatments were. Using separate $A$. esculenta morphometric data sampled from Ventry in 2013 and 2014, we estimated frond surface area (length multiplied by maximum width of frond) and correlated this with frond weight. The regression slope relating frond surface area to frond weight was significant, with $\mathrm{R}^{2}=0.7792$ and slope $=0.017( \pm 0.0004 \mathrm{SE})$. This allowed us to calculate seeded frond surface area per $10 \mathrm{~cm}$ section from our total sample biomass data per section. The results, presented in Table 5, show that seeded surface area lies between artificial low and artificial high surface area for $10 \mathrm{~cm}$ sections. The differences between fouling communities (A. esculenta intermediate between high and low density artificial treatments) are therefore consistent with a frond density effect. Peteiro \& Freire (2013a), and Peteiro et al. (2016 and references therein) have indicated that high densities of fronds in a reduced space (e.g. dropper rope) can modify the environment via reduction in currents. Thus, the observed density effect probably altered the hydrodynamic environment experienced by the frond communities i.e. high density frond communities experience less disturbance with low density communities experiencing more hydrodynamic activity. However, some caution is needed before generalising the effect of density, as the different treatment substrates may have specific surface chemistries and specific microenvironments (Michael et al. 2008) which could be responsible for the differences in epibiont communities.

Alterations in hydrodynamic environment could explain the species compositional differences and variations in species occurrence between artificial treatments. For example, increased hydrodynamic conditions may prevent the settlement of fouling organisms such as hydroids and bryozoans on algal fronds (Fraschetti et al. 2006, Saunders \& Metaxas 2008, Peteiro \& Freire 2013b). The nudibranch Polycera quadrilineata had higher occurrence on high density fronds, with the sheltered conditions providing a favourable habitat for itself and its prey species (bryozoans). The opposite pattern was true for the decapod Necora puber and the red algae Ceramium sp., which could be attributed to increased water currents circulating more nutrients and food particles over the
Table 5. Surface area $\left(\mathrm{cm}^{2}\right)$ and standard error for seeded, artificial low and artificial high treatments per $10 \mathrm{~cm}$ section. na: not applicable

\begin{tabular}{|lcc|}
\hline Treatment & $\begin{array}{c}\text { Surface area }\left(\mathrm{cm}^{2}\right) \\
\text { per } 10 \mathrm{~cm} \text { section }\end{array}$ & SE \\
\hline Seeded & 4889.44 & 1379.18 \\
Artificial low & 3000 & na \\
Artificial high & 9000 & na \\
\hline
\end{tabular}

low density fronds. As this tests the impact of smallscale hydrodynamics, multivariate differences in frond fouling communities on seaweed farms caused by hydrodynamic differences over larger spatial scales need to be researched (Peteiro \& Freire 2013b).

These results support the use of artificial droppers as experimental mimics of cultivated fronds for use at potential seaweed farm sites. This will enable an assessment of the potential fouling communities likely to affect cultivated fronds without using seeded tissue, which can be harvested and sold, while also controlling factors such as biomass, productivity and algal anti-fouling.

\section{Succession of fouling kelp communities}

No comparison can be made between succession on our seeded fouling kelp communities and other kelp studies as no published descriptions of succession in fouling assemblages were found using an International Scientific Index (ISI) search for succession, kelp, epibionts and other variants of these keywords. This lack of information is probably due to the focus in the cultivation industry on increasing production and not ecological implications. Studies of succession are, of course, common in other systems, such as rocky shores and artificial substrates. The timing of disturbance or the creation of new substrata can have an enormous impact on succession (Dayton et al. 1984, Benedetti-Cecchi \& Cinelli 1993, Underwood \& Chapman 2006) because of seasonality in organisms' reproductive patterns and/or growth and seasonal variation in environmental conditions (Jenkins \& Martins 2010). This effect of timing was apparent in the initial differences in fouling on seeded $A$. esculenta between years. However, initial differences may not persist as communities transition to similar end-points (Underwood \& Chapman 2006, Jenkins \& Martins 2010). A number of studies suggest that varying successional trajectories ultimately converge towards the local climax communities (Underwood \& 
Chapman 2006, Antoniadou 2014, Evans et al. 2016). Our epibiotic fouling communities followed this pattern of convergence from different start points to similar end-points.

\section{Implications for the kelp cultivation industry}

The ability to understand the timing of occurrences of fouling organisms and predict their arrival has significant benefits for the seaweed cultivation industry. With this knowledge, seaweed farmers can exert some control over the quality of their crop by being able to decide on a date-by-site basis when is the optimum time to deploy in order to achieve a harvest of optimal quality and yield. Earlier harvesting of fronds could avoid the period when the most severe fouling occurs (late May to June in SW Ireland); this approach has been very effective for kelpproducing farms in Asia (Park et al. 2008, Park \& Hwang 2012). Early deployment of juvenile kelp seedlings to sea would allow for a longer cultivation period in the cooler winter months, leading to increased growth of fronds while fouling rates are low (Peteiro \& Freire 2009). The crop would then reach harvestable size earlier in the season, before an increase in seawater temperature and associated fouling organisms (Park et al. 2008, Peteiro \& Freire 2009, 2013b, Park \& Hwang 2012, Førde et al. 2016).

Acknowledgements. The authors acknowledge Dr. Benoît Quéguineur, Mr. David Moran and Mr. Brendan Walls for their assistance in field sampling. In addition, we thank Dr. Adrian Patterson and Mr. Jack O'Carroll from NUI Galway's Benthic Ecology Laboratory for taxonomic support, Mr. Michael Murphy and Mr. Paul Flannery of Dingle Bay Seaweed for boat work and assistance at Ventry Harbour, and staff at Dingle Oceanworld Aquarium for providing laboratory space. This work was supported by the Energetic Algae project (EU Interreg IVB NWE Strategic Initiative; www. enalgae.eu). The authors also acknowledge the 2 anonymous reviewers and editor Symon Dworjanyn for their comments that have helped to improve the manuscript. A.M.W. is currently funded by the Dr. Tony Ryan Research Trust, NUI Galway.

\section{LITERATURE CITED}

Al-Ogily SM, Knight-Jones EW (1977) Anti-fouling role of antibiotics produced by marine algae and bryozoans. Nature 265:728-729

Alldredge AL, Hamner WM (1980) Recurring aggregation of zooplankton by a tidal current. Estuar Coast Mar Sci 10: 31-37

Antoniadou C (2014) Succession patterns of polychaetes on algal-dominated rocky cliffs (Aegean Sea, Eastern Mediterranean). Mar Ecol (Berl) 35:281-291
Baselga A (2010) Partitioning the turnover and nestedness components of beta diversity. Glob Ecol Biogeogr 19: 134-143

Benedetti-Cecchi L, Cinelli F (1993) Early patterns of algal succession in a midlittoral community of the Mediterranean sea: a multifactorial experiment. J Exp Mar Biol Ecol 169:15-31

* Blight AJ, Thompson RC (2008) Epibiont species richness varies between holdfasts of a northern and a southerly distributed kelp species. J Mar Biol Assoc UK 88:469-475

Bruton $\mathrm{T}$, Lyons $\mathrm{H}$, Lerat $\mathrm{Y}$, Stanley M, Rasmussen MB (2009) A review of the potential of marine algae as a source of biofuel in Ireland. Sustainable Energy Ireland, Dublin

Bunker FSD, Maggs CA, Brodie JA, Bunker AR (2012) Seaweeds of Britain and Ireland. Wild Nature Press, Plymouth

Buschmann AH, Gómez P (1993) Interaction mechanisms between Gracilaria chilensis (Rhodophyta) and epiphytes. Hydrobiologia 260-261:345-351

*Buschmann AH, Varela DA, Hernández-González MC, Huovinen P (2008) Opportunities and challenges for the development of an integrated seaweed-based aquaculture activity in Chile: determining the physiological capabilities of Macrocystis and Gracilaria as biofilters. J Appl Phycol 20:571-577

Cancino JM, Mufioz J, Mufioz M, Orellana MC (1987) Effects of the bryozoan Membranipora tuberculata (Bosc.) on the photosynthesis and growth of Gelidium rex Santelices et Abbott. J Exp Mar Biol Ecol 113:105-112

Christie H, Jørgensen NM, Norderhaug KM, Waage-Nielsen E (2003) Species distribution and habitat exploitation of fauna associated with kelp (Laminaria digitata) along the Norwegian coast. J Mar Biol Assoc UK 83:687-699

Clarke KR, Gorley RN (2006) PRIMER v6: user manual/ tutorial. Primer-E, Plymouth

Clarke KR, Warwick RM (1994) Changes in marine communities: an approach to statistical analysis and interpretation, 2nd edn. Primer-E, Plymouth

Colebrook JM (1979) Continuous plankton records: seasonal cycles of phytoplankton and copepods in the North Atlantic Ocean and the North Sea. Mar Biol 51:23-32

* D'Antonio C (1985) Epiphytes on the rocky intertidal red alga Rhodomela larix (Turner) C. Agardh: negative effects on the host and food for herbivores? J Exp Mar Biol Ecol 86:197-218

* Dayton PK (1985) Ecology of kelp communities. Annu Rev Ecol Syst 16:215-245

* Dayton PK, Currie V, Gerrodette T, Keller BD, Rosenthal R, Tresca DV, Ven D (1984) Patch dynamics and stability of some California kelp communities. Ecol Monogr 54: 253-289

* Dixon J, Schroeter SC, Kastendiek J (1981) Effects of the encrusting bryozoan, Membranipora membranacea, on the loss of blades and fronds by the giant kelp, Macrocystis pyrifera (Laminariales). J Phycol 17:341-345

* Druehl LD, Baird R, Lindwall A, Lloyd KE, Pakula S (1988) Longline cultivation of some Laminariaceae in British Columbia, Canada. Aquacult Res 19:253-263

* Edwards M, Richardson AJ (2004) Impacts of climate change on marine pelagic phenology and trophic mismatch. Nature 430:881-884

Edwards M, Watson L (2011) Cultivating Laminaria digitata. Aquaculture explained, No. 26. Bord Iscaigh Mhara, Dublin 
Evans AJ, Firth LB, Hawkins SJ, Morris ES, Goudge H, Moore PJ (2016) Drill-cored rock pools: an effective method of ecological enhancement on artificial structures. Mar Freshw Res 67:123-130

FAO (2016) The state of world fisheries and aquaculture 2016. FAO, Rome

Fletcher RL (1995) Epiphytism and fouling in Gracilaria cultivation: an overview. J Appl Phycol 7:325-333

Fletcher WJ, Day RW (1983) The distribution of epifauna on Ecklonia radiata (C. Agardh) J. Agardh and the effect of disturbance. J Exp Mar Biol Ecol 71:205-220

Førde H, Forbord S, Handå A, Fossberg J, Ariff J, Johnsen G, Reitan KI (2016) Development of bryozoan fouling on cultivated kelp (Saccharina latissima) in Norway. J Appl Phycol 28:1225-1234

Fraschetti S, Terlizzi A, Bevilacqua S, Boero F (2006) The distribution of hydroids (Cnidaria, Hydrozoa) from microto macro-scale: spatial patterns on habitat-forming algae. J Exp Mar Biol Ecol 339:148-158

Getachew P, Kang JY, Choi JS, Hong YK (2015) Does bryozoan colonization alter the biochemical composition of Saccharina japonica affecting food safety and quality? Bot Mar 58:267-274

Guiry M, Blunden G (1991) Seaweeds resources in Europe: uses and potential. Wiley \& Sons, Chichester

Handå A, Forbord S, Wang X, Broch OJ and others (2013) Seasonal- and depth-dependent growth of cultivated kelp (Saccharina latissima) in close proximity to salmon (Salmo salar) aquaculture in Norway. Aquaculture 414415:191-201

Hayward PJ (1988) Animals on seaweed. Richmond Publishing Company, Surrey

Hayward PJ, Ryland JS (eds) (2002) Handbook of the marine fauna of north-west Europe. Oxford University Press, Oxford

Hepburn CD, Hurd CL, Frew RD (2006) Colony structure and seasonal differences in light and nitrogen modify the impact of sessile epifauna on the giant kelp Macrocystis pyrifera (L.) C Agardh. Hydrobiologia 560:373-384

Herben T (2005) Species pool size and invasibility of island communities: a null model of sampling effects. Ecol Lett 8:909-917

Hood GM (2014) PopTools version 3.2.5. www.poptools.org

* Hurd C, Durante K, Harrison P (2000) Influence of bryozoan colonization on the physiology of the kelp Macrocystis integrifolia (Laminariales, Phaeophyta) from nitrogenrich and -poor sites in Barkley Sound, British Columbia, Canada. Phycologia 39:435-444

Jenkins S, Martins G (2010) Succession on hard substrata. In: Dürr S, Thomason J (eds) Biofouling. Wiley-Blackwell, Oxford, p 60-72

Jennings JG, Steinberg PD (1997) Phlorotannins versus other factors affecting epiphyte abundance on the kelp Ecklonia radiata. Oecologia 109:461-473

Jessopp M, Mulholland OR, McAllen R, Johnson MP, Crowe TP, Allcock AL (2007) Coastline configuration as a determinant of structure in larval assemblages. Mar Ecol Prog Ser 352:67-75

Kraan S, Guiry MD (2001) Phase II: Strain hybridisation field experiments and genetic fingerprinting of the edible brown seaweed Alaria esculenta. Marine Resource Series No. 18, Marine Institute, Dublin

Kraan S, Verges Tramullas A, Guiry MD (2000) The edible brown seaweed Alaria esculenta (Phaeophyceae, Laminariales): hybridization, growth and genetic comparisons of six Irish populations. J Appl Phycol 12:577-583

* Krumhansl KA, Lee JM, Scheibling RE (2011) Grazing damage and encrustation by an invasive bryozoan reduce the ability of kelps to withstand breakage by waves. J Exp Mar Biol Ecol 407:12-18

Kruskal JB (1964a) Nonmetric multidimensional scaling: a numerical method. Psychometrika 29:115-129

Kruskal JB (1964b) Multidimensional scaling by optimizing goodness-of-fit to a nonmetric hypothesis. Psychometrika 29:115-129

* Leonardi PI, Miravalles AB, Faugeron S, Flores V, Beltrán J, Correa JA (2006) Diversity, phenomenology and epidemiology of epiphytism in farmed Gracilaria chilensis (Rhodophyta) in northern Chile. Eur J Phycol 41:247-257

* Marzinelli EM, Underwood AJ, Coleman RA (2011) Modified habitats influence kelp epibiota via direct and indirect effects. PLOS ONE 6:e21936

McCulloch A, Shanks AL (2003) Topographically generated fronts, very nearshore oceanography, and the distribution of chlorophyll, detritus, and selected diatom and dinoflagellate taxa. J Plankton Res 25:1427-1439

* Michael TS, Shin HW, Hanna R, Spafford DC (2008) A review of epiphyte community development: surface interactions and settlement on sea grass. J Environ Biol 29: 629-638

*Moore PJ, Thompson RC, Hawkins SJ (2011) Phenological changes in intertidal con-specific gastropods in response to climate warming. Glob Change Biol 17:709-719

Murata M, Nakazoe JI (2001) Production and use of marine algae in Japan. Jpn Agric Res Q 35:281-290

Norton TA, Hoscock K, Kitching JA (1977) The ecology of Lough Ine. XX. The Laminaria forest at Carrigathorna. J Ecol 65:919-941

*Park CS, Hwang EK (2012) Seasonality of epiphytic development of the hydroid Obelia geniculata on cultivated Saccharina japonica (Laminariaceae, Phaeophyta) in Korea. J Appl Phycol 24:433-439

Park TS, Rho YG, Gong YG, Lee DY (1990) A harpacticoid copepod parasitic in the cultivated brown alga Undaria pinnatifida in Korea. Bull Korean Fish Soc 23:439-442

Park CS, Park KY, Baek JM, Hwang EK (2008) The occurrence of pinhole disease in relation to developmental stage in cultivated Undaria pinnatifida (Harvey) Suringar (Phaeophyta) in Korea. J Appl Phycol 20:485-490

* Peteiro C, Freire Ó (2009) Effect of outplanting time on commercial cultivation of kelp Laminaria saccharina at the southern limit in the Atlantic coast, NW Spain. Chin J Oceanology Limnol 27:54-60

Peteiro C, Freire Ó (2012) Observations on fish grazing of the cultured kelps Undaria pinnatifida and Saccharina latissima (Phaeophyceae, Laminariales) in Spanish Atlantic waters. AACL Bioflux 5:189-196

* Peteiro C, Freire Ó (2013a) Biomass yield and morphological features of the seaweed Saccharina latissima cultivated at two different sites in a coastal bay in the Atlantic coast of Spain. J Appl Phycol 25:205-213

* Peteiro C, Freire Ó (2013b) Epiphytism on blades of the edible kelps Undaria pinnatifida and Saccharina latissima farmed under different abiotic conditions. J World Aquacult Soc 44:706-715

* Peteiro C, Sánchez N, Martínez B (2016) Mariculture of the Asian kelp Undaria pinnatifida and the native kelp Saccharina latissima along the Atlantic coast of southern Europe: an overview. Algal Res 15:9-23

Ryland J (1962) The association between polyzoa and algal 
substrata. J Anim Ecol 31:331-338

Ryland JS, Hayward PJ (1977) British anascan bryozoans. Academic Press, London

Saier B, Chapman AS (2004) Crusts of the alien bryozoan Membranipora membranacea can negatively impact spore output from native kelps (Laminaria longicruris). Bot Mar 47:265-271

Saunders M, Metaxas A (2008) High recruitment of the introduced bryozoan Membranipora membranacea is associated with kelp bed defoliation in Nova Scotia, Canada. Mar Ecol Prog Ser 369:139-151

Seed R, Harris S (1980) The epifauna of the fronds of Laminaria digitata Lamour in Strangford Lough, Northern Ireland. Proc R Ir Acad B 80B:91-106

Seed R, O'Connor R (1981) Community organization in marine algal epifaunas. Annu Rev Ecol Syst 12:49-74

* Shepard R (1962) The analysis of proximities: multidimensional scaling with an unknown distance function. II. Psychometrika 27:219-246

Sloane JF, Ebling FJ, Kitching JA, Lilly SJ (1957) The ecology of the Lough Ine rapids with special reference to water currents. V. The sedentary fauna of the laminarian algae in the Lough Ine area. J Anim Ecol 26:197-211

Underwood AJ, Chapman MG (2006) Early development of subtidal macrofaunal assemblages: relationships to period and timing of colonization. J Exp Mar Biol Ecol 330: 221-233

Vairappan CS (2006) Seasonal occurrences of epiphytic al-

Editorial responsibility: Symon Dworjanyn,

Coffs Harbour, New South Wales, Australia gae on the commercially cultivated red alga Kappaphycus alvarezii (Solieriaceae, Gigartinales, Rhodophyta). J Appl Phycol 18:611-617

Wahl M (1997) Living attached: aufwuchs, fouling, epibiosis. In: Nagabhushanam R, Thompson M (eds) Fouling organisms of the Indian Ocean: biology and control technology. Oxford and IBH Publishing, New Delhi, p 31-83

Walls AM, Kennedy R, Fitzgerald RD, Blight AJ, Johnson MP, Edwards MD (2016) Potential novel habitat created by holdfasts from cultivated Laminaria digitata: assessing the macroinvertebrate assemblages. Aquacult Environ Interact 8:157-169

WWłodarska-Kowalczuk M, Kukliński P, Ronowicz M, Legeżyńska J, Gromisz S (2009) Assessing species richness of macrofauna associated with macroalgae in Arctic kelp forests (Hornsund, Svalbard). Polar Biol 32:897-905

WoRMS Editorial Board (2016) World register of marine species. www.marinespecies.org

* Yamanaka R, Akiyama K (1993) Cultivation and utilization of Undaria pinnatifida (wakame) as food. J Appl Phycol 5:249-253

* Yorke AF, Metaxas A (2011) Interactions between an invasive and a native bryozoan (Membranipora membranacea and Electra pilosa) species on kelp and Fucus substrates in Nova Scotia, Canada. Mar Biol 158:2299-2311

Zagal CJ, Underwood J, Chapman MG (2013) Distribution of hydroids along fronds of the kelp Ecklonia radiata. Hydrobiologia 720:89-99

Submitted: August 10, 2016; Accepted: December 14, 2016 Proofs received from author(s): January 24, 2017 